Revista Brasileira de Engenharia Agrícola e Ambiental

Brazilian Journal of Agricultural and Environmental Engineering

\title{
Multi-criteria analysis for selection of priority management programs for the Japaratuba River Basin, SE, Brazil ${ }^{1}$
}

\author{
Análise multicritério para seleção de programas \\ de gestão prioritários para a Bacia do Rio Japaratuba, SE, Brasil
}

\author{
Carla Z. A. dos Santos ${ }^{2 \star} \oplus$, Talitha S. C. Bezerra ${ }^{2}$, Alceu Pedrotti $^{3} \oplus$, \\ Arisvaldo V. Méllo Júnior ${ }^{4} \odot$ \& Laura J. Gomes ${ }^{5}$

\footnotetext{
${ }^{1}$ Research developed at Japaratuba River Basin in the State of Sergipe, Brazil

${ }^{2}$ Universidade Federal de Sergipe/Programa de Pós-Graduação em Desenvolvimento e Meio Ambiente, São Critovão, SE, Brazil

${ }^{3}$ Universidade Federal de Sergipe/Departamento de Agronomia, São Critovão, SE, Brazil

${ }^{4}$ Universidade de São Paulo/Escola Politécnica/Departamento de Engenharia Hidráulica e Ambiental, São Paulo, SP, Brazil

${ }^{5}$ Universidade Federal de Sergipe/Departamento de Ciências Florestais, São Critovão, SE, Brazil
}

\section{HIGHLIGHTS:}

The priority scale of the JRPB programs was established based on the analysis of the critical levels of six criteria observed. The multicriteria analysis proved to be effective in defining priorities in the execution of river basin plans programs. Forest restoration programs have a higher execution priority due to the high degree of deforestation observed in BHJ.

\begin{abstract}
The Japaratuba River Basin (JRB), located in Sergipe, Brazil, has accelerated economic development due to oil exploration and an increase in the sugarcane and corn monocultures. Thus, environmental degradation has increased in the basin. Given the importance of the water supply that the hydrographic basin has for the state of Sergipe, and the need to balance its economic growth with environmental conservation, this study had the objective to analyze the Japaratuba River Basin Plan (JRBP), published in 2015, and propose the priority scale for the execution of programs arranged under the scope of a Strategic Environmental Assessment (SEA). Thus, the multi-criteria decision analysis (MCDA) applying the Analytic Hierarchy Process method (AHP) was used with data collection (water supply and distribution, sanitation, and forest cover) for the years 2018, 2019, and 2020, associating Geoprocessing techniques. It was verified that among the criteria analyzed for the definition of the priority scale, those associated with the restoration of ecosystems, sanitation, and hygiene, and water quality were the ones with the highest priority for execution according to the levels of criticality observed. The multi-criteria analysis expands the context of environmental criteria to be observed in further reviews of the JRBP; and expands the strategic environmental vision in the integrated management processes of the basin.
\end{abstract}

Key words: environmental management, environmental planning, water resources, 2030 Agenda, sustainable development

RESUMO: A Bacia Hidrográfica do Rio Japaratuba (BHJ), localizada no Estado de Sergipe, apresenta um acelerado desenvolvimento econômico em decorrência da exploração do petróleo e aumento da monocultura da cana de açúcar e do milho; em consequência observa-se o aumento da degradação ambiental na bacia. Dada a importância para o abastecimento hídrico que a bacia hidrográfica possui para o Estado de Sergipe, e a necessidade de equilibrar o crescimento econômico com a conservação ambiental, este estudo teve o objetivo de analisar o Plano da Bacia Hidrográfica do Rio Japaratuba (PBHJ), publicado em 2015, e propor a escala de prioridade para execução dos programas dispostos sob o escopo de uma Avaliação Ambiental Estratégica (AAE). Para isso utilizou-se a análise multicritério de decisão aplicando-se o método Processo Hierárquico Analítico, com coleta de dados (abastecimento e distribuição de água, saneamento e cobertura florestal) dos anos de 2018, 2019 e 2020, associando também, técnicas de geoprocessamento. Constatou-se que, dos seis critérios analisados para a definição da escala de prioridade, aqueles associados à restauração dos ecossistemas, saneamento e higiene e a qualidade da água foram os que apresentaram a mais alta prioridade para execução, conforme os níveis de criticidade observados. A análise multicritério adotada sob uma abordagem de variáveis do desenvolvimento sustentável amplia o contexto de critérios ambientais a serem observados em futuras revisões do PBHJ; e expande a visão ambiental estratégica nos processos de gestão integrada da bacia.

Palavras-chave: planejamento ambiental, recursos hídricos, Agenda 2030, desenvolvimento sustentável

- Ref. 243042 - Received 01 Sept, 2020

* Corresponding author - E-mail: doczoaid@gmail.com

- Accepted 06 Apr, 2021 • Published 09 May, 2021

Edited by: Walter Esfrain Pereira
This is an open-access article distributed under the Creative Commons Attribution 4.0 International License.

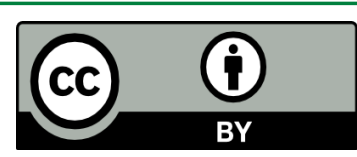




\section{INTRODUCTION}

The water availability of the basins, hydraulic infrastructures, climate changes, the multiple demands for use and their potential conflicts, and the different development perspectives make water resources management a challenging task.

The preparation of a Water Resources Plan (WRP) should consider a wide scope of strategic variables associated with aspects of sustainability that should be considered in the initial stages of formulating the plan, for example (Pizella \& Souza, 2013; Souza \& Teixeira, 2016; Pizella, 2019). Also, there is a need to reassess the strategies adopted in the plans periodically.

The Japaratuba River Basin (JRB) is included in this context, evaluated as one of the most degraded in the state of Sergipe, mainly because of the pressure of urbanization on ecosystems and the lack of adequate sanitation (Maynard et al., 2017), there is an urgent need to revaluation its Japaratuba River Basin Plan (JRBP), was approved in 2015.

According to the JRBP diagnosis analysis, the basin presents two main axes of pressure: (i) high rate of urbanization in the municipalities of the basin and (ii) expansion of the sugarcane and corn agribusiness. These pressures result in critical factors that imply an increase in the demand for management and planning strategies.

It is considered that the hierarchic analytic process (AHP), a multi-criteria analysis methodology (MCDA) useful to assess the importance of the factors associated with the sustainable development of the basin and assist in decision-making. This methodology has been tested in several applications, such as zoning of protected areas, the definition of priority areas for forest restoration, and selection of priority conservation practices, for example (Flenger et al., 2015; Valente et al., 2017; Singh et al., 2018).

Given the need, this research elaborated and analyzed the scale of priorities for executing the 24 programs adopted in the JRBP. It was considered the level of criticality of the impact factors in the Basin was considered according to the selection of 6 analysis criteria, which were defined based on the United Nations Sustainable Development (SDG) objectives (UN, 2015).

\section{Material And Methods}

The study area is located in the state of Sergipe, Brazil, between the Southern latitudes $10^{\circ} 13^{\prime}$ and $10^{\circ} 47^{\prime}$ and Western longitudes $36^{\circ} 49^{\prime}$ and $36^{\circ} 19^{\prime}$, and the average altitude of 144 $\mathrm{m}$. The JRB has $1,674.24 \mathrm{~km}^{2}$, equivalent to $7.65 \%$ of the state's territory, covering 18 municipalities (Sergipe, 2015).

Rainfall is distributed throughout the year in well-defined dry and rainy periods where the rainy season is between October and January with values lesser than $45 \mathrm{~mm}$ (on average), and the rainy season from April to August, with values greater than $155 \mathrm{~mm}$. The average flow of the Japaratuba River is around $11.0 \mathrm{~m}^{3} \mathrm{~s}^{-1}$ and the minimum (Q7.10 - an average of the lowest flows of seven consecutive days with a 10 -year recurrence) of $0.22 \mathrm{~m}^{3} \mathrm{~s}^{-1}$ (Sergipe, 2015).

The Japaratuba River Basin (JRB) is the smallest in the state of Sergipe; however, it has an important role, as it covers densely populated areas. The urbanization rate of the municipalities located in the watershed is approximately $65 \%$. This anthropic interference is the result of the industrialization process in the state, which started in the 1970 and 1980s, and the extraction of oil that boosted the economic development of the region (Sergipe, 2015) (Figure 1).

This research was developed in three steps: 1 . Documental analysis; 2 . Definition of sustainability criteria, and 3. Multicriteria analysis for decision making: The documental analysis was carried out for the JRBP by systematizing the programs proposed in the document (Sergipe, 2015).

The sustainability criteria were defined based on the specific goals of the sustainable development goal six: "Ensuring the availability and sustainable management of water and sanitation for all" of the "Agenda 2030: our common future" (UN, 2015). The essentiality of this goal was analyzed, transforming it into a sustainability criterion, understood as essential for a sustainable development path in the water resources management, resulting in six criteria.

A. Access to water; B. Sanitation and Hygiene; C. Water quality; D. Sustainable Use; E. Ecosystem restoration; and F. Integrated Management. The parameterization of each criterion was performed as follows:

Criterion A - Access to water (Ab); it corresponds to the total water supply index (urban and rural) made available in the National Sanitation Information System - SNIS (Brazil, 2018a), which indicates the population effectively attended by the water supply network (\% water supply corresponding to the municipalities that make up the basin). The average national coverage rate is $92.78 \%$, and this rate is $94.55 \%$ for Sergipe (Brasil, 2018a). Based on this data, the following qualitative scale was defined for the criterion: If $\mathrm{Ab} \geq 95 \%$ - excellent; if $85 \% \leq \mathrm{Ab} \leq 94 \%$ - good; if $75 \% \leq \mathrm{Ab} \leq 84 \%$ - reasonable; if $65 \% \leq \mathrm{Ab} \leq 74 \%$ - bad; and if $\mathrm{Ab} \leq 64 \%$ - terrible.

Criterion B - Sanitation and Hygiene (St); it corresponds specifically to the "Index of treated sewage of the consumed water", which indicates the portion of the total population (urban and rural) that was effectively served by a sewage collection network (with or without treatment) concerning the total resident population of the providers that answered the SNIS (Brasil, 2018a). The Brazilian average for this index is $53.15 \%$, and for the state of Sergipe, this value is only $25.40 \%$ (Brasil, 2018a). Considering this relationship, the following
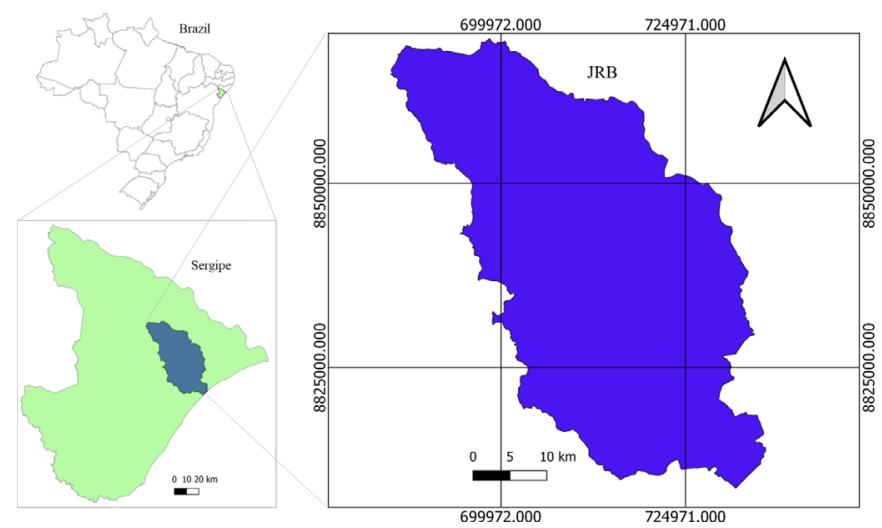

Figure 1. Localization of the Japaratuba River Basin Plan (JRB), SE, Brazil 
qualitative scale was defined for the criterion: if the percentage of collected sewage treatment St $\geq 80 \%$ - excellent; if $75 \% \leq$ St $<80 \%$ - good; if $65 \% \leq \mathrm{St} \leq 74 \%$ - reasonable; if $55 \% \leq \mathrm{St} \leq$ $64 \%$ - good; and if St $\leq 54 \%$ - terrible. However, from the 18 municipalities that make up the watershed, only two answered the SNIS collection questionnaire (Brazil, 2018a) for this question: Aquidabã (SE) and Barra dos Coqueiros (SE).

Criterion C - Water quality; it was assessed using the Water Quality Index (WQI) of the basin, used by ANA - Brazilian Water Agency as the main qualitative indicator of the country (Brazil, 2020). The WQI is calculated based on the following parameters: water temperature, $\mathrm{pH}$, dissolved oxygen, total residue, biochemical oxygen demand, thermotolerant coliforms, total nitrogen, total phosphorus, and turbidity (Eq. 1). This study used the values of 10 fluviometric monitoring stations distributed in the Japaratuba River Basin (Brazil, 2020; Sergipe, 2020). The water classification used was defined according to the quality scale proposed by ANA (Brazil, 2020): if WQI $\geq 91$ - optimal condition; if $71 \leq \mathrm{WQI} \leq 90$ - good; 51 $\leq \mathrm{WQI} \leq 70$ - reasonable; if $26 \leq \mathrm{WQI} \leq 50$ - bad; and if WQI $\leq 25$ - terrible.

$$
\mathrm{WQI}=\prod_{\mathrm{i}=1}^{\mathrm{n}} \mathrm{q}_{\mathrm{i}} \mathrm{w}_{\mathrm{i}}
$$

where:

$\mathrm{q}_{\mathrm{i}} \quad$ - i-th water quality parameter. A number between 0 and 100 obtained from the respective quality graph, depending on this concentration;

$\mathrm{w}_{\mathrm{i}}$ - weight corresponding to the $\mathrm{i}$-th parameter set according to its importance for the global quality index. A number between 0 and 1 , so the sum is one; and,

$\mathrm{n}$ - number of parameters that enter the WQI calculation.

Criterion D - Sustainable use of water: it was assessed by efficiency, measured by the "Index of losses in the distribution network at the final destination (Lw\%)" according to Eq. 2, available on SNIS (Brasil, 2018a). The average national loss rate is $38.45 \%$, and for the state of Sergipe, this rate is $48.7 \%$. Considering this relationship, the qualitative scale was defined for the criterion: if $\mathrm{Lw} \leq 15 \%$ - excellent; if $15 \%<\mathrm{Lw} \leq 30 \%$ - good; if $29 \% \leq \mathrm{Lw} \leq 45 \%$ - reasonable; if $46 \% \leq \mathrm{Lw} \leq 55 \%$ bad; and if $\mathrm{Lw} \geq 56 \%$ - terrible.

$$
\mathrm{Lw}=\frac{\mathrm{AG} 006+\mathrm{AG} 018-\mathrm{AG} 010-\mathrm{AG} 024}{\mathrm{AG} 006+\mathrm{AG} 018-\mathrm{AG} 024} 100
$$

where:

AG006 - annual volume of treated water available for consumption $\left(1000 \mathrm{~m}^{3}\right.$ year $\left.{ }^{-1}\right)$;

AG010 - annual volume of water consumed by all users $\left(1000 \mathrm{~m}^{3}\right.$ year $\left.^{-1}\right)$;

AG018 - annual volume of drinking water, previously treated $\left(1000 \mathrm{~m}^{3}\right.$ year $\left.^{-1}\right)$; and,

AG024 - Sum of annual volumes of water used for operational activities (disinfection of pipelines and networks, hydraulic tests and cleaning of reservoirs), special (own consumption, transported by water trucks, washing streets, and irrigating public green spaces), and water volume recovered $\left(1000 \mathrm{~m}^{3}\right.$ year $\left.^{-1}\right)$.

Criterion E - Restoration of the ecosystem. The percentage of legal forest cover in the basin was assessed by the provisions required by Brazilian Forest Code (Law number 12,651/2012), specifically. For the restoration of ecosystems, it was observed the status of the vegetation cover in the areas of permanent preservation of the riverbanks (PPA) and the conservation units $(\mathrm{CoU})$ of the basin. The percentage of vegetation cover in these areas was calculated using remote sensing data representing land use and occupation (MAPBIOMAS, 2020). The QGIS software version 3.10 was used to perform the spatial analysis.

The qualitative analysis assumed that the best situation is when $100 \%$ of the legal forest cover (Cf) is established within their respective zones. The closer to $0 \%$, the worse the situation for the basin. Thus, the following scale was adopted: if $\mathrm{Cf} \geq$ $80 \%$ - optimal; if $60 \% \leq \mathrm{Cf}<80 \%$ - good; if $40 \% \leq \mathrm{Cf} \leq 59 \%$ reasonable; if $20 \% \leq \mathrm{Cf} \leq 39 \%$ - bad; and if Cf $\leq 19 \%$ - terrible.

Criterion F - Integrated management: it was assessed by analyzing the state of Sergipe Institutional Arrangement for Integrated Management (Sergipe, 2015), responding to the following items: the existence of a specific agency, the publication of a state plan for river basins, availability of information systems on water resources, and institutionalization of activities of the watershed committee of the studied area.

Each item received a value between zero and one to represent the condition of integrated resource management. The value zero represents failure, and the value one indicates success in implementing integrated management of water resources. The final consolidated value of this criterion is the average of the responses. This information was collected in the State Water Resources System (Sergipe, 2020).

In all criteria, the values were divided into five classes, with class 1 being the lowest priority and class 5 being the highest priority for implementing the management program in the basin. This classification was standardized for the entire area of the basin.

The multi-criteria analysis was performed using the AHP Method (Analytic Hierarchy Process) based on Saaty (1987), which approaches the ranking of factors (criteria) in a weighted and parameterized way with a differentiated determination of weights for the evaluated criteria through a pairwisecomparison matrix.

Once the parameters are generated, decision-makers can systematically evaluate the elements, promote comparisons and analyze the established hierarchy, therefore, defining priorities according to the objective of the study (Flenger et al., 2015; Valente et al., 2017; Galetti et al., 2018; Gomes \& Bias, 2018; Almeida et al., 2019).

The criteria are compared pairwise on a scale from one to nine, where one represents equal importance among them. Nine represents the total predominance of one over the other (Saaty, 1987). As the matrix elaborated for the criteria is paired, the relationship of importance is inverse.

In this classification scale about importance intensity of the criteria proposed by Saaty (1987) the score 1 is attributed 
when comparisons between criteria have equal importance (two criteria contribute identically), the score 3 when one criterion is little more important than another, the score 5 when the criterion is much more important (predominant over other to achieve the objective), the score 7 when the criterion is significantly more important than the other, and the score 9 when the criterion is extremely important (absolutely the most important for the objective). The scores $2,4,6$, and 8 correspond to intermediate values.

The weight assignment (comparison) process for each selected criterion was established considering the document analysis of the Basin diagnosis (Sergipe, 2015), the database available in Sergipe (2020), and the literature review on the importance of each criterion for sustainable development related to UN-based water resource management (2015). The authors of this study attributed the important values in the comparison matrix, drawing inspiration from Valente et al. (2017) and Almeida et al. (2019).

Afterward, the following equations were calculated: (a) the eigenvalue for each line of the matrix given by the geometric mean of the values (Eq. 3), (b) the Author's Normalization value (Eq. 4), (c) the eigenvalue given by the sum of the values of each line of the pairwise comparison matrix for the criteria (Eq. 5), (d) maximum Lambda ( $\chi_{\max }$ (Eq. 6), (e) the consistency index (Eq. 7), and (f) consistency ratio of the matrix values (Eq. 8). According to the method AHP, the $\mathrm{CR}<0.10$ indicates a reasonable level of consistency in the matrix; $C R \geq 0.10$ indicates an inconsistency level in the weights assigned in the matrix, so the weight distribution should be reviewed (Saaty \& Vargas, 2012).

$$
\begin{gathered}
\overline{\mathrm{g}_{\mathrm{i}}}=\sqrt[\mathrm{n}]{1 \mathrm{x}_{1} \mathrm{x}_{2} \ldots \mathrm{x}_{\mathrm{n}}} \\
\mathrm{N}_{\mathrm{i}}=\frac{\overline{\mathrm{g}_{\mathrm{i}}}}{\sum_{\mathrm{i}=1}^{\mathrm{n}} \overline{\mathrm{g}_{\mathrm{i}}}} \\
\mathrm{AV}_{\mathrm{i}}=\mathrm{x}_{1}+\mathrm{x}_{2}+\cdots+\mathrm{x}_{\mathrm{n}} \\
{\left[\begin{array}{ccc}
1 & 1 / \mathrm{x}_{1} & 1 / \mathrm{x}_{\mathrm{n}} \\
\mathrm{x}_{1} & 1 & 1 / \mathrm{x}_{2} \\
\mathrm{x}_{\mathrm{n}} & \mathrm{x}_{2} & 1
\end{array}\right]\left[\begin{array}{c}
\mathrm{N}_{1} \\
\mathrm{~N}_{2} \\
\mathrm{~N}_{\mathrm{n}}
\end{array}\right]=\lambda \max \left[\begin{array}{l}
\mathrm{N}_{1} \\
\mathrm{~N}_{2} \\
\mathrm{~N}_{\mathrm{n}}
\end{array}\right]} \\
\mathrm{CI}=\frac{\lambda \max -\mathrm{n}}{\mathrm{n}-1} \\
\mathrm{CR}=\frac{\mathrm{CI}}{\mathrm{IR}}
\end{gathered}
$$

where:

$g_{i} \quad$ geometric mean of line $i$ of the comparison matrix;

$\mathrm{x}_{1}, \ldots, \mathrm{x}_{\mathrm{n}}$ - values of the line for each criterion;

$\mathrm{n}$ - number of columns in the matrix;

$\mathrm{N}_{\mathrm{i}}$ - normalization of the geometric mean for line $\mathrm{i}$;

$A V_{i}$ - eigenvector of line $i$;

$\lambda \max$ - convergence factor between the comparison matrix and the normalized eigenvectors;
CI - weight consistency index;

IR - $\mathrm{n}$-dependent average random index (in this case it was $I R=1.25)$; and,

CR - consistency ratio.

The weights defined for each criterion need to be associated with producing an overall result. The Weighted Linear Combination (WLC) method was used to aggregate these weights for each established criterion, thus producing a priority scale for the programs. In this method, the criteria are multiplied by their respective weights from the AHP (Eq. 9) (Saaty, 1987).

$$
\mathrm{S}=\sum_{\mathrm{i}=1}^{\mathrm{n}} \mathrm{w}_{\mathrm{i}} \mathrm{x}_{\mathrm{i}} \prod_{\mathrm{j}=1}^{\mathrm{k}} \mathrm{c}_{\mathrm{j}}
$$

where:

$\mathrm{S}$ - weighted sum;

$\mathrm{w}_{\mathrm{i}} \quad$ - standardized weight associated with the criterion $\mathrm{i}$;

$\mathrm{x}_{\mathrm{i}} \quad$ - value of criterion $\mathrm{i}$;

$c_{j} \quad$ - count 0 or 1 used as an exclusion criterion $j(0$ value does not exist; 1 - value exists);

$\mathrm{n}$ - number of criteria; and,

$\mathrm{k}$ - number of exclusion criteria.

For the application of the multi-criteria AHP method, the programs set out in the Plan were grouped according to the defined sustainability criteria, identifying 24 macro-actions divided between programs and subprograms distributed into four axes: infrastructure, sanitation, hydro-environmental and institutional; and areas thematic: assessment of hydrological potential, expansion, and improvement of the supply and sewage systems, meeting the goal of framing water bodies, encouraging good practices in the use of water, recovery, and monitoring of environmental conservation areas, and communication on water resources (Sergipe, 2015).

\section{Results ANd Discussion}

For the 24 actions defined in the Japaratuba River Basin Plan (JRBP), the Access to Water (criterion A) is associated with $8 \%$ of the programs; the Sanitation and Hygiene (criterion B) gathers $25 \%$ of the programs; the Water Quality (criterion C) gathers $8 \%$ of the programs; Sustainable use (criterion D) contains 17\%; the Ecosystem Restoration criterion (criterion E) has only $4 \%$, and the Integrated Management (criterion F) was the one that most brought together programs, $38 \%$ of them.

The weights calculated for each criterion, their respective eigenvectors, and normalized weights are shown in Table 1 . The importance values in the second column of Table 1 indicate that criterion A has equal importance over itself, it is much more important than $\mathrm{B}$ and $\mathrm{E}$, it is significantly more important than $\mathrm{C}$, it is little more important than $\mathrm{D}$, and little less important that $\mathrm{F}$. The values above the diagonal are reciprocal to those at the bottom (inverse value). The $\mathrm{CR}=0.0787$, indicating that the matrix presented an adequate level of consistency.

The quality scale was standardized in a range from one to five, in which one means "Very Small Priority" for the execution 
Table 1. Paired matrix for the Japaratuba River Basin $(J R B)$, with consistency ratio $=0.08 . A=$ Access to water $\%$; $B=$ collected and treated sewage $\% ; \mathrm{C}=$ Water quality; $\mathrm{D}=$ Sustainable use - loss \%; E = Forest cover \%; F = Integrated management (yes $/$ no)

\begin{tabular}{ccccccccccc}
\hline & A & B & C & D & E & F & Eigenvector $^{1}$ & Normalization $^{2}$ & Eigenvalue & Xmax \\
A & 1 & 0.2 & 0.143 & 0.333 & 0.2 & 3 & 0.42281763 & 0.048974227 & 21.333333 & 1.044784 \\
B & 5 & 1 & 0.333 & 3 & 0.333 & 7 & 1.50594804 & 0.17443133 & 7.7 & 1.338962 \\
C & 7 & 3 & 1 & 3 & 3 & 7 & 3.313294 & 0.383773054 & 2.2853141 & 0.877042 \\
D & 3 & 0.333 & 0.333 & 1 & 0.2 & 3 & 0.764699 & 0.088573749 & 12.6666 & 1.121928 \\
E & 5 & 3 & 0.333 & 5 & 1 & 7 & 2.36465211 & 0.273893522 & 4.876157 & 1.335548 \\
F & 0.333 & 0.143 & 0.143 & 0.333 & 0.143 & 1 & 0.26206143 & 0.030354117 & 28 & 0.849915 \\
\hline
\end{tabular}

Table 2. Standardized criteria $(S)$ for Japaratuba River Basin $(J R B)$ with consistency ratio $=0.08 . A=\%$ of access to water; $B=$ treated and collected sewage $\% ; \mathrm{C}=$ Water quality; $\mathrm{D}=$ Sustainable use - loss \%; E = Forest cover \%; F= Integrated management (yes/no)

\begin{tabular}{|c|c|c|c|c|c|c|c|c|}
\hline \multicolumn{7}{|c|}{ Standardization criteria } & \multirow{2}{*}{ Classification } & \multirow{2}{*}{ Qualification } \\
\hline & $\bar{A}$ & $\bar{B}$ & $\mathbf{C}$ & $\mathbf{D}$ & $\mathbf{E}$ & $\mathbf{F}$ & & \\
\hline \multirow{5}{*}{ Scale } & $\geq 95$ & $\geq 80$ & $\geq 91$ & $\leq 15$ & $\geq 80$ & Consolidated (1) & 1 & Very Small priority \\
\hline & $94-85$ & $80-75$ & $71-90$ & $15-30$ & $80-60$ & - & 2 & Small priority \\
\hline & $84-75$ & $74-65$ & $51-70$ & $29-45$ & $59-40$ & - & 3 & Average priority \\
\hline & $74-65$ & $64-55$ & $26-50$ & $46-55$ & $39-20$ & - & 4 & High priority \\
\hline & $\leq 64$ & $\leq 54$ & $\leq 25$ & $\geq 56$ & $\leq 19$ & Not consolidated (0) & 5 & Very high priority \\
\hline Mean & $84 \%$ & $4.42 \%$ & 57.89 & $51.70 \%$ & $7.8 \%$ & Yes & & \\
\hline
\end{tabular}

of the programs associated with the criterion, and five means "Very High Priority" to execute the programs due to the level of criticality found (Table 2). The bottom row of Table 2 represents the mean values of the criteria in the watershed.

Once the weights of each analyzed criterion were standardized (Table 2), the importance degree of the criteria was defined by multiplying the normalization value (Table 1) by the standardized weight (classification) of Table 2, resulting in the final ranking of the criteria (Table 3).

According to the analyses and the demonstration of the final result in Table 3, the Ecosystem Restoration (E) was the criterion with the greatest weight (1.3694) to define priority programs for execution. However, there is only one program in the Plan, out of a total of 24, focused on this criterion: "Plan for the assessment, recovery, and monitoring of strategic areas for environmental conservation and preservation" (Sergipe, 2015). Valente et al. (2017) and Almeida et al. (2019) obtained the highest weight $(0.87$ and 0.51$)$ for forest proximity to the drainage network. According to the authors, forested riparian areas are very important for forest restoration due to the connected fragments and improve water quality.

The result obtained is from the high level of degradation of the basin ecosystems, so this criterion deserves priority, and urgent attention since only $7.8 \%$ of the basin area is covered by forest formations, according to the calculation methodology

Table 3. Final weight for the ranking of programs in the Japaratuba River Basin (JRBP), according to established criteria: $\mathrm{A}=$ Access to water $\% ; \mathrm{B}=$ sewage collected and treated $\% ; \mathrm{C}=$ Water quality; $\mathrm{D}=$ Sustainable use - loss $\%$; $\mathrm{E}=$ Forest cover $\% ; \mathrm{F}=$ Integrated management (yes/no)

\begin{tabular}{cccc}
\hline Criterion & $\begin{array}{c}\text { Standardized } \\
\text { weight }\end{array}$ & $\begin{array}{c}\text { Normalization } \\
\text { value }\end{array}$ & $\begin{array}{c}\text { Criterium final } \\
\text { weight }\end{array}$ \\
\hline A & 3 & 0.048974227 & 0.1469 \\
B & 5 & 0.17443133 & 0.8721 \\
C & 2 & 0.383773054 & 0.7675 \\
D & 5 & 0.088573749 & 0.4428 \\
E & 5 & 0.273893522 & 1.3694 \\
F & 1 & 0.030354117 & 0.0303 \\
\hline
\end{tabular}

adopted by MAPBIOMAS (2020). This situation is even more critical at upstream of the basin (Figure 2).

The data shown in this study for the forest cover of the Hydrographic Basin are from three years (2018) after the publication of the JRBP (2015), and the scenario presented shows a more critical situation than that observed in the period that the Plan was published, in which coverage was $13 \%$ (Sergipe, 2015). The situation is further aggravated by specifically assessing the PPAs on riverbanks (Figure 2), where $44 \%(7,221 \mathrm{ha})$ of the area needs to be recovered.

Forest restoration has been identified as one of the most emergent and urgent actions for balancing environmental conservation. It is also considered one of the most important ecosystem services links, especially for hydrological services (Chadzon, 2008; Montoya et al., 2012; Fengler et al., 2015; Valente et al., 2017; Bermer et al., 2019; França et al., 2020).

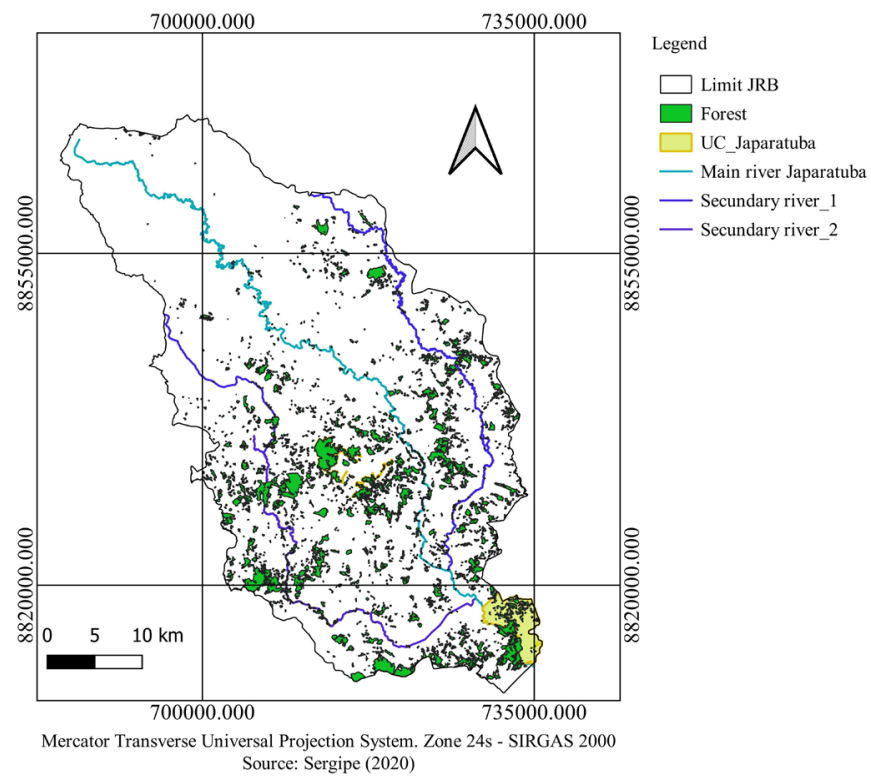

Figure 2. Forest cover of the Japaratuba River Basin (JRB). MapBiomas 4.1 Collection, 2018 data. Source: Prepared by the Authors, 2020 based on MAPBIOMAS, 2020 and Sergipe, 2020 
Therefore, the program (Forest restoration) needs to be dismembered into multiple other actions to accelerate its execution and obtain more effective results. Programs such as payments for environmental services (PES) aimed at landowners and other forms of financial compensation (tax discounts, payment for adopting strategies, etc.) could be included in a revision of the Plan as an incentive to restore the riparian forests of the PPAs.

PES is an economic instrument based on the user-payer and provider-receiver principle to finance environmental conservation (Campanha et al., 2019) and the provision of environmental ecosystem services. In 2001, the Brazilian National Water Agency implemented the Water Producer Program (Brasil, 2018b), and in recent years, there has been an increase in PES initiatives in the country (Chiodi et al., 2013; Taffarello et al., 2016; Cruz et al., 2017).

Forest recovery, in particular, becomes even more critical when realizing that although the Government has its forest diagnosis and inventory, it does not yet have a state law on forests, a fact that hinders concrete forest recovery actions.

Sanitation and hygiene (B) (Table 3 ) was the second most important criterion (0.8721) for selecting priority programs to be executed. This criterion is directly linked to the capacity of the system to collect and treat the sewage from the water consumed, which, as observed, is assessed as inefficient and insufficient.

The marked rate of urbanization observed for the basin, the growing rate of anthropization, and changes in physical and biological aspects are the probable causes of the levels of criticality observed for this criterion.
The lack of effluent treatment stations, including the industrial ones, has aggravated this problem. Thus, programs already established in the Plan, such as: "Supporting the preparation of municipal basic sanitation plans; Adequacy of the collection and final destination of solid waste, and Expansion and improvement of the Supply and Sewage Systems" (Sergipe, 2015), are extremely urgent and have a high priority for implementation and efficient operation.

The water quality criterion (C) was the third most important, with a value of 0.7675 (Table 3 ). The water quality is directly related to its intensity of use and status found when it returns to other water bodies after consumption. Research results have been shown that the quality of water has been affected by the not-processed discharges and that the speed and quantity of effluent discharge in the basin is more intense than the purification capacity, mainly in the downstream region where the quality levels are more critical (Edokpayi et al., 2017).

The sustainable use criterion (D) was the fourth most important, with a value of 0.443 (Table 3 ). The average percentage of water loss in the Basin is over $50 \%$ (Brasil, 2018a), so discussing and defining sustainable strategies on efficient use and implementing the best practices is also a high priority. Associating environmental education programs having this focus is a strategy that must be enhanced and jointly implemented (Alcântara et al., 2012) and the programs for the efficient and economical use of water such as rainwater harvesting, reuse, etc.

The fifth most important criterion was access to water (A) with a value of 0.147 (Table 3). Currently, the basin has a good water distribution and meets current needs. Although this

Table 4. Level of priority for the execution according to the level of criticality observed for the analyzed sustainability criteria

\begin{tabular}{|c|c|c|c|}
\hline Priority & Proposed program and subprogram for the plan & Criterion & $\begin{array}{c}\text { Program } \\
\%\end{array}$ \\
\hline Very high & $\begin{array}{l}\text { 1. Assessment, recovery, and monitoring planning of strategic areas for environmental conservation and preservation. } \\
\text { 2. Program: Support in the elaboration of city plans for basic sewage. } \\
\text { 3. Program: Adjustment in the collection and final destination of solid waste. } \\
\text { 4. Program: Extension and improvement of the supply and sewage systems. } \\
\text { 4.1 Subprogram: extension and improvement of the supply and sewage system. } \\
\text { 4.2 Subprogram: water supply to the diffuse rural population. } \\
\text { 4.3 Subprogram: loss reduction in the water supply system. } \\
\text { 4.4 Subprogram: sanitary sewage system (generation, collection, and treatment of the effluents). } \\
\text { 5. Program of actions for underground water use. } \\
\text { 6. Program for the stimulation of good practices in water use. } \\
\text { 6.1 Subprogram: water producer. } \\
\text { 6.2 Subprogram: good practices statement. } \\
\text { 6.3 Subprogram: reuse support. }\end{array}$ & $\begin{array}{l}B \\
B \\
B \\
B \\
D\end{array}$ & 45.9 \\
\hline Intermediate & $\begin{array}{l}\text { 7. Program for the control and reduction in the use of pesticides. } \\
\text { 8. Program for the extension of the qualitative -quantitative monitoring network: one of the actions to meet the adjustment goals. } \\
\text { 8.1 Sub-program: actions needed for achieving the adjustment goal. }\end{array}$ & C & 8.3 \\
\hline Small & $\begin{array}{l}\text { 9. Evaluation program of the hydrological program. } \\
\text { 9.1 Subprogram: actions needed to attend the adjustment goal. } \\
\text { 9.2 Subprogram: hydrometric network modernization and complementation. }\end{array}$ & $\begin{array}{l}A \\
A\end{array}$ & 8.3 \\
\hline Very low & $\begin{array}{l}\text { 10. Water-resource communication and education program. } \\
\text { 10.1 Subprogram: communication plan on water resources. } \\
\text { 10.2 Subprogram: communication and environmental education as social agents for environment conservation. } \\
\text { 10.3 Subprogram: communication and education for water -resource users. } \\
\text { 11. Water-environmental supe rvision for strengthening the program. } \\
\text { 11.1 Subprogram: water-environment inspection system. } \\
\text { 11.2 Subprogram: strengthening of the environment municipality agencies. } \\
\text { 12. SEGERH improvement program. } \\
\text { 12.1 Subprogram: institutional strengthening of SEGERH -SE management and execution agencies. } \\
\text { 12.2 Subprogram: development of human reSources for water resources management. } \\
\text { 12.3 Subprogram: internal communication SEGERH-SE. } \\
\text { 12.4 Subprogram: strengthening of SEGERH collegiate agencies. }\end{array}$ & $\begin{array}{l}F \\
F \\
F\end{array}$ & 37.5 \\
\hline
\end{tabular}

Source: Based on Sergipe (2015) 
criterion has presented the penultimate priority, its importance should not be overlooked, especially given the future economic and population growth perspective. Furthermore, the nonexecution of programs associated with the criteria highest priority may affect the results for water access on a long-term time scale.

The lowest priority criterion was the integrated management (F) within the established scale with a value of 0.0303 (Table 3).

According to the analysis of the results obtained, the factors related to the physical and environmental aspects of the basin (ecosystem restoration - forest cover, sanitation and hygiene, water quality, sustainable use, and access to water - water supply) weighed more than the factors related to integrated management. However, this does not mean that the integrated management criterion is less important, but that the level of criticality of the other criteria analyzed, at this moment, is more pronounced, requiring faster and further efficient intervention and operationalization measures.

When elaborating a sustainability index for the JRB, Maynard et al. (2017) concluded that this Basin needs priority attention regarding sewage collection and treatment, water supply, and the recovery of protected areas. These factors can guarantee better water availability, given the fundamental interaction between forest cover and the water cycle.

The AHP method defined the priority programs for the sustainable management of JRB from the perspective of SEA. Thus, the experimental results indicated the programs with the highest execution priority and those with the smallest priority according to the data analyzed for the study period and its association with the analyzed criterion (Table 4 ). The JRBP predicted 24 programs and subprograms, 11 (45.9\%) of which met criteria $\mathrm{B}, \mathrm{D}$, and $\mathrm{E}$, which received very high priority; two $(8.3 \%)$ of criterion $\mathrm{C}$ with intermediate; two (8.3\%) of criterion A with low priority; and nine $(37.5 \%)$ of criterion $\mathrm{F}$ with very low implementation priority. The six criteria are important for sustainable management in the Basin and must work together to prepare efficient planning.

The JRBP included few programs related to ecosystem restoration and biodiversity conservation (Sergipe, 2015). The results showed that a future review of the JRBP should focus on environmental preservation actions, particularly forest restoration and sanitation (collection and treatment of sewage).

\section{Conclusions}

1. The adopted methodology allows establishing a priority scale for the execution of the Basin Plan programs of the Japaratuba River, SE, based on the criticality level of the factors observed for each established criterion.

2. Within the basin plan review scope, the methodology applied in this research is effective. It can be used to define priorities; therefore better understanding the criticality levels and expanding the strategic environmental vision in the integrated management processes of the basin.

3. Considering aspects of the future sustainability of the basin and the levels of criticisms found in the data collection, the analysis showed that programs related to the criteria $\mathrm{E}=$ Forest cover criterion are the highest priority for execution, followed hierarchically by the programs related to the criteria
$\mathrm{B}=$ Sewage collected, with the criteria $\mathrm{C}=$ Water quality and criterion $\mathrm{D}=$ Sustainable use; and programs related to criteria $\mathrm{A}=$ Acess to water and criteria $\mathrm{F}=$ Integrated management is the lowest priority for execution.

\section{Literature Cited}

Alcântara l. A.; Silva, M. C. A.; Araújo, R. K. de; Nishijima, T. Práticas de educação ambiental na gestão de recursos hídricos. Revista Eletrônica em Gestão, Educação e Tecnologia Ambiental, v.5, p.741-748, 2012. https://doi.org/10.5902/223611704199

Almeida, F. C. de; Silveira, E. M. de O.; Paiva, L. L. de; Arcebi Júnior, F. W. Mapping of priority areas for forest recovery using multicriteria analysis in the brazilian atlantic forest. Raega: Espaço Geográfico em Análise, v.46, p.113-124, 2019. https://doi.org/10.5380/raega. v46i3.67075

Brasil - Ministério do Desenvolvimento Regional. Sistema de informações sobre saneamento - SNIS. Dados 2018a. Available on: <http://www.snis.gov.br/>. Accessed on: Set. 2020.

Brasil - Agência Nacional de Águas e Saneamento Básico. Nota informativa - programa produtor de água. 2018b. Available on: <https:/www.ana.gov.br/programas-e-projetos/programaprodutor-de-agua $>$. Accessed on: Set. 2020.

Brasil - Agência Nacional de Águas e Saneamento Básico. Portal da qualidade das águas. 2020. Avaliable on: <http://pnqa.ana.gov. br/rede-nacional-rede-monitoramento.aspx. $>$ Accessed on: Set. 2020.

Bremer L. L.; Wada, C. A.; Medoff, S.; Page, J.; Falinski, K.; Burnett, K. M. Contributions of native forest protection to local water supplies in East Maui. Science of the Total Environment, v.688, p.1422-1432, 2019. https://doi.org/10.1016/j.scitotenv.2019.06.220

Campanha, M. M. Serviços ecossistêmicos: histórico e evolução. In: Ferraz, R. P. D.; Prado, R. B.; Parron, L. M.; Campanha, M. M. (eds). Marco referencial em serviços ecossistêmicos. Brasília: Embrapa, 2019, p.37-56. Avaliable on: <https://www.embrapa.br/ busca-de-publicacoes/-/publicacao/1110948/marco-referencialem-servicos-ecossistemicos $>$. Accessed on: Jan. 2021.

Chadzon, R. L. Deforestation: Restoring forests and ecosystem services on degraded lands. Science, v.320, p.1468-1460, 2008. https://doi. org/10.1126/science. 1155365

Chiodi, R. E.; Sarcinelle, O.; Uezu, A. Gestão dos recursos hídricos na área do Sistema Produtor de Água Cantareira: Um olhar para o contexto rural. Revista Ambiente \& Água, v.8, p.151-165, 2013.

Cruz, P. P. N. da; Green, T. R.; Figueiredo, R. de O.; Pereira, A. S.; Kipka, H.; Saad, S. I.; Silva, J. M. da; Gomes, M. A. F. Hydrological modeling of the Ribeirão das Posses - An assessment based on the Agricultural Ecosystem Services (AgES) watershed model. Revista Ambiente \& Água, v.12, p.351-364, 2017. https://doi. org/10.4136/ambi-agua.2073

Edokpayi, J. N.; Odiyo, J. O.; Durowoju, O. S. Impact of wastewater on surface water quality in developing countries: A case study of South Africa. In: Tutu, H. (ed.). Water quality. London: InTech Open, 2017. p.401-416. https://doi.org/10.5772/66561

França, L. C. de J.; Mucida, D. P.; Santana, R. C.; Morais, M. S. de; Gomide, L. R.; Bateira, C. V. de M. AHP approach applied to multi-criteria decisions in environmental fragility mapping. Revista Floresta, v.50, p.1623-1632, 2020. https://doi. org/10.5380/rf.v50i3.65146 
Fengler, F. H.; Moraes, J. F. L.; Ribeiro, A. I.; Peche Filho, A.; Storino, M.; Medeiros. G. A. de. Qualidade ambiental dos fragmentos florestais na Bacia Hidrográfica do Rio Jundiaí-Mirim entre 1972 e 2013, Revista Brasileira de Engenharia Agrícola e Ambiental, v.19, p.402-408, 2015. https://doi.org/10.1590/18071929/agriambi.v19n4p402-408

Galetti, G.; Silva, J. M. S. da; Pina-Rodrigues, F. C. M.; Piotrowiski, I. Análise multicriterial da estabilidade ecológica em três modelos de restauração florestal. Revista Brasileira de Ciências Ambientais, n.48, p.142-157, 2018. https://doi.org/10.5327/ Z2176-947820180301

Gomes, R. C.; Bias, E. S. Integração do método AHP e SIG como instrumento de análise do nível de conservação ambiental em bacias hidrográficas. Revista Geociências, v.37, p.167-182, 2018. https://doi.org/10.5016/geociencias.v37i1.10236

MAPBIOMAS. Projeto MapBiomas - coleção versão 4.1 da série anual de mapas de cobertura e uso de solo do brasil, 2020. Avaliable on: <https://mapbiomas.org/>. Accessed on: Jun. 2020.

Maynard, I. F. N.; Cruz, M. A. S.; Gomes, L. J. Aplicação de um índice de sustentabilidade na bacia hidrográfica do rio Japaratuba em Sergipe. Ambiente \& Sociedade, v.20, p. 207-226, 2017.

Montoya, D.; Rogers, L.; Memmott, J. Emerging perspectives in the restoration of biodiversity-based ecosystem services. Trends in Ecology and Evolution, v.27, 2012. https://doi.org/10.1016/j. tree.2012.07.004

Pizella, D. G. Avaliação ambiental estratégica como instrumento para a gestão integrada dos recursos hídricos: Estudo de caso do plano de bacia do são José dos Dourados e do plano diretor municipal de Ilha Solteira, SP. Holos Environment, v.19, p.388355, 2019. https://doi.org/10.14295/holos.v19i3.12250

Pizella, D. G.; Souza, M. P. de. Avaliação ambiental estratégica de planos de bacias hidrográficas. Revista de Engenharia Sanitária Ambiental, v.18, p.243-252, 2013. https://doi.org/10.1590/ S1413-41522013000300007
Saaty, T. L. The analytic hierarchy process-what it is and how it is used. Mathematical Modelling, v.9, p.161-176, 1987. https://doi. org/10.1016/0270-0255(87)90473-8

Saaty, T. L.; Vargas, L. G. Models, methods, concepts \& application softhe analytic hierarchy process. 2.ed. Springer: London, 2012. 341p. https://doi.org/10.1007/978-1-4614-3597-6

Sergipe. Elaboração dos planos das bacias hidrográficas dos rios Japaratuba, Piauí e Sergipe: relatório final da Bacia hidrográfica do rio Japaratuba. 2015. https://sedurbs.se.gov.br/.

Sergipe. Portal de recursos hídricos. 2020. https://sedurbs.se.gov.br/. Singh, A. S.; Eanes, F. R.; Prokopy, L. S. Assessing conservation adoption decision criteria using the analytic hierarchy process: case studies from three midwestern watersheds. Society \& Natural Resources, v.31, p.503-507, 2018. https://doi.org/10.10 80/08941920.2017.1413694

Souza, M. C. da S. A. de; Teixeira, H. T. A avaliação ambiental estratégica no planejamento da gestão de recursos hídricos: uma necessidade para o equilíbrio do meio ambiente. Revista de Direito Ambiental e Socioambientalismo, v.2, p.190-209, 2016. https://doi.org/10.26668/IndexLawJournals/2525-9628/2016. v2i1.1057

Taffarello, D.; Guimarães, J.; Lombardi, R. K. de S.; Calijuri, M. C.; Mendiondo, E. M. Hydrologic monitoring plan of the Brazilian Water Producer/PCJ Project. Journal of Environmental Protection, v.7, p.1956-1970, 2016. https://doi.org/10.4236/ jep.2016.712152

UN - United Nations Organization. Transforming our world: The 2030 agenda for sustainable development. 2015. https:// sustainabledevelopment.un.org.

Valente, A. R.; Petean, F. C. de S.; Vettorazzi, C. A. Multicriteria decision analysis for prioritizing areas for forest restoration. Cerne, v.23, p.53-60, 2017. https://doi.org/10.1590/010477602 01723012258 